\title{
Carbon plasma immersion ion implantation and DLC deposition on $\mathrm{Ni}-\mathrm{Ti}$ alloy
}

\section{S. Viswanathan, L. Mohan, Manjusha Chakraborty, Chitra Mandal, Parthasarathi Bera, S. T. Aruna \& C. Anandan}

To cite this article: S. Viswanathan, L. Mohan, Manjusha Chakraborty, Chitra Mandal, Parthasarathi Bera, S. T. Aruna \& C. Anandan (2018) Carbon plasma immersion ion implantation and DLC deposition on Ni-Ti alloy, Materials and Manufacturing Processes, 33:10, 1121-1127, DOI: $10.1080 / 10426914.2017 .1415450$

To link to this article: https://doi.org/10.1080/10426914.2017.1415450

\section{册 Published online: 08 Jan 2018.}

\section{Ш山l}

Submit your article to this journal $\pi$

山 Article views: 131

Q View related articles $\square$

View Crossmark data ¿

Citing articles: 4 View citing articles 4 


\title{
Carbon plasma immersion ion implantation and DLC deposition on $\mathrm{Ni}-\mathrm{Ti}$ alloy
}

\author{
S. Viswanathan ${ }^{a}$, L. Mohan ${ }^{a}$, Manjusha Chakraborty ${ }^{b}$, Chitra Mandal $^{b}$, Parthasarathi Bera ${ }^{a}$, S. T. Aruna ${ }^{a}$, and C. Anandan ${ }^{a}$ \\ aSurface Engineering Division, CSIR-National Aerospace Laboratories, Bengaluru, India; ${ }^{b}$ Cancer Biology and Inflammatory Disorder Division, CSIR- \\ Indian Institute of Chemical Biology, Kolkata, India
}

\begin{abstract}
Carbon plasma immersion ion implantation (PIII-C) has been performed on $\mathrm{Ni}-\mathrm{Ti}$ alloy surface using methane as a precursor gas at low temperature and it has been followed by deposition of diamond-like carbon (DLC) coating. Untreated and coated alloys are characterized with field emission scanning electron microscopy, atomic force microscopy, Raman spectroscopy, and X-ray photoelectron spectroscopy. Electrochemical impedance spectroscopy, and corrosion testing in Hanks' solution which is simulated body fluid show that corrosion resistance has been enhanced in PIII-C + DLC-coated alloy compared to untreated alloy. The in vitro studies of untreated and PIII-C + DLC-coated alloys have been evaluated using osteoblast-like cells (MG-63). Cellular behavior in terms of cell morphology along with the viability and cell spreading has been evaluated using scanning electron microscopy and in vitro cell culture assay, respectively. In comparison to $\mathrm{Ni}-\mathrm{Ti}$ alloy, the coated alloy exhibits better cell viability indicating their biocompatibility.
\end{abstract}

\section{ARTICLE HISTORY}

Received 30 September 2017

Accepted 29 November 2017

\section{KEYWORDS}

Corrosion; DLC; ElS; in vitro; $\mathrm{Ni}-\mathrm{Ti}$; PIII; XPS

\section{Introduction}

In the past few decades, $\mathrm{Ni}-\mathrm{Ti}$ alloy is the most widely investigated material in the biomedical industry because of its unique properties like shape memory effect, super elasticity, corrosion resistance, and good biocompatibility. ${ }^{[1,2]} \mathrm{Ni}-\mathrm{Ti}$ alloy is used in numerous biomedical applications as an implant and in particular as orthodontic dental arch wires, orthopedic implants, and cardiovascular stent. ${ }^{[3-5]}$ However, one of the disadvantages of the $\mathrm{Ni}-\mathrm{Ti}$ alloy is the leaching of harmful $\mathrm{Ni}$ ions from the implants during corrosion and wear in physiological environment that can induce carcinogenic, toxic, and allergic responses. ${ }^{[6,7]}$ In this sense, it is necessary to develop a barrier layer for impeding the out diffusion of $\mathrm{Ni}$ ions from implants. There are numerous techniques that have been used to modify the $\mathrm{Ni}-\mathrm{Ti}$ alloy surface such as heat treatment, ${ }^{[8,9]}$ sol-gel deposition, ${ }^{[10]}$ electrochemical process, ${ }^{[1-13]}$ etc. Plasma immersion ion implantation (PIII) technique is well-known and widely used method for surface modification of $\mathrm{Ni}-\mathrm{Ti}$ alloy and also irregular shaped substrates. ${ }^{[14-17]}$ Diamond-like carbon (DLC) coating has drawn much attention nowadays in both biomedical and engineering applications because of its low coefficient of friction, high hardness, wear resistance, chemical inertness, and good biocompatibility. ${ }^{[18-20]}$ In the present work, DLC coating has been developed on $\mathrm{Ni}-\mathrm{Ti}$ alloy using carbon plasma immersion ion implantation method. This coating has been investigated with field emission scanning electron microscopy (FESEM), atomic force microscopy (AFM), Raman spectroscopy, X-ray photoelectron spectroscopy (XPS), electrochemical impedance spectroscopy (EIS), and potentiodynamic polarization studies in simulated body fluid (SBF). In addition, Ni-Ti alloy and PIII-C+ DLC-coated alloys have been tested for their efficacy on osteoblast-like cells (MG-63) in in vitro cell culture assays along with cell morphology by scanning electron microscopy.

\section{Materials and Methods}

Silicon wafers (100) were cut into pieces with sizes of $1.5 \mathrm{~cm} \times 1.5 \mathrm{~cm}$ and were cleaned in acetone ultrasonically. These silicon substrates were used for thickness measurement and cross-sectional analysis. $\mathrm{Ni}-\mathrm{Ti}$ alloy with $50 \%$ of $\mathrm{Ni}$ (Johnson Matthey Noble Metals) were cut in the form of sheet $(20 \mathrm{~mm} \times 30 \mathrm{~mm} \times 1 \mathrm{~mm})$ and were polished with 1200 grit emery paper and mirror finished with $0.3 \mu \mathrm{m}$ alumina powder and then the substrates were ultrasonically cleaned with acetone and dried.

Carbon plasma immersion ion implantation (PIII-C) was performed in a custom-designed plasma-enhanced chemical vapor deposition (PECVD) chamber. Chamber made of stainless steel (SS 304) was pumped down up to $5 \times 10^{-6}$ mbar using turbo molecular pump backed with rotary pump. After the base pressure was reached, the chamber and the gas lines were purged with $\mathrm{Ar}$ and $\mathrm{CH}_{4}$. Before implantation, $\mathrm{Ni}-\mathrm{Ti}$ substrate surface was cleaned by $\mathrm{Ar}^{+}$sputtering at $5 \mathrm{kV}$ for $20 \mathrm{~min}$ duration to remove undesirable contaminants. $\mathrm{CH}_{4}$ gas flow of $10 \mathrm{sccm}$ was used for carbon implantation (PIII-C). The gas flow was controlled using a mass flow controller (MKS Instruments, USA) and throttle valve. Process pressure in the chamber was also monitored by a Baratron manometer (MKS Instruments, USA). Carbon plasma was generated using inductive coupling of $50 \mathrm{~W}$ RF power $(13.56 \mathrm{MHz})$ and the sample 
was biased with negative pulsed bias voltage of $20 \mathrm{kV}$ with $40 \mu \mathrm{s}$ pulse. Pulse rate of $25 \mathrm{~Hz}$ was applied to the substrate and the implantation time was $60 \mathrm{~min}$ at a pressure of $4.5 \mu \mathrm{bar}$. The substrate temperature was maintained at less than $80^{\circ} \mathrm{C}$ during deposition and it was continuously monitored using a thermocouple attached with the substrate holder. After carbon implantation, the samples were cooled down to room temperature under vacuum. Further, on the same sample, DLC coating was developed using $10 \mathrm{sccm}$ of $\mathrm{CH}_{4}$ with constant $50 \mathrm{~W} \mathrm{RF}$ power and substrate holder was biased with $-150 \mathrm{~V}$ DC voltage and deposition time of $60 \mathrm{~min}$ at a pressure of $4.5 \mu \mathrm{bar}$.

The microstructure of the coatings was obtained using FESEM (Carl Zeiss SUPRA 40VP) and elemental analysis was performed by INCAPentaFETx 3 energy dispersive X-ray spectrometer from Oxford Instruments attached to FESEM facility. Surface topography was investigated by AFM with CSEM Instruments (Model SSI) operated in contact mode. $I_{\mathrm{D}} / I_{\mathrm{G}}$ ratio was evaluated using micro Raman spectrometer (LABRAM 010A) from DILOR-JOBIN-YVON SPEX having $\mathrm{He}-\mathrm{Ne}$ laser source with wave length of $632.8 \mathrm{~nm}$. XPS of untreated and PIII-C + DLC-coated Ni-Ti alloys were performed using SPECS spectrometer. Mild $\mathrm{Ar}^{+}$ion sputter etching of PIII-C + DLCcoated alloy surface was performed to understand subsurface layer. Details of XPS experiments are described elsewhere. ${ }^{[12,13]}$

Electrochemical studies were performed in $200 \mathrm{ml}$ of SBF on untreated Ni-Ti and PIII-C + DLC-coated samples at $37 \pm 2{ }^{\circ} \mathrm{C}$. A conventional three-electrode cell consisting of saturated calomel electrode (SCE), $\mathrm{Pt}$, and $\mathrm{Ni}-\mathrm{Ti}$ as reference, counter, and working electrodes, respectively, was used to conduct the electrochemical studies using $\mathrm{CH} 604 \mathrm{D}$ electrochemical workstation. For obtaining steady-state potential, samples were immersed in Hanks' solution for $1 \mathrm{~h}$ and continuously monitored. EIS was carried over a frequency range of $10-100 \mathrm{~Hz}$ with sinusoidal perturbation potential amplitude of $10 \mathrm{mV}$ on the $\mathrm{E}_{\mathrm{OCP}}$. The detailed procedure has been reported elsewhere. ${ }^{[12,13,21]}$

For in vitro studies an alpha-minimal essential medium was procured from GIBCO (CA, USA). Fetal bovine serum,

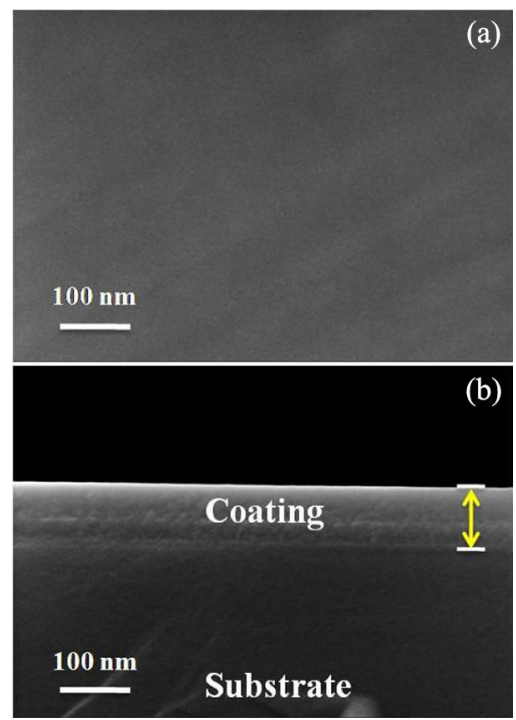

Figure 1. FESEM images of PIIIC + DLC coating: (a) top surface on $\mathrm{Ni}-\mathrm{Ti}$ alloy and (b) cross-sectional image on Si substrate. Note: FESEM, field emission scanning electron microscopy; DLC, diamond-like carbon.
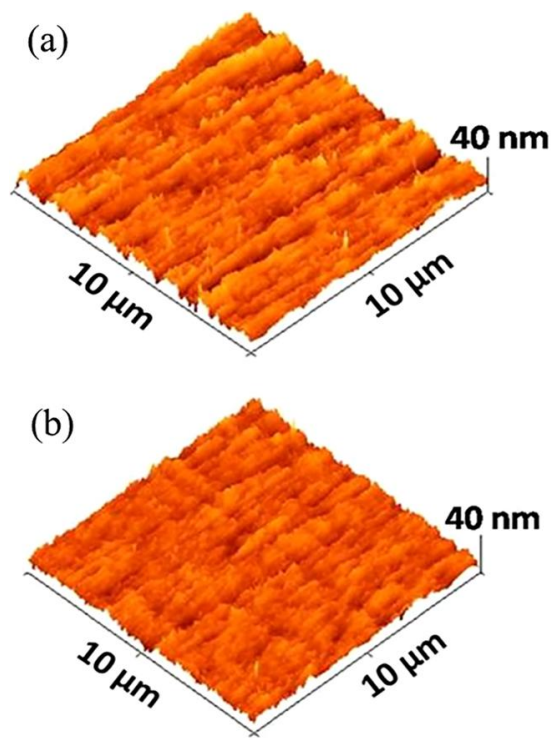

Figure 2. Surface topographies: (a) untreated $\mathrm{Ni}-\mathrm{Ti}$ alloy and (b) PIII-C + DLCcoated $\mathrm{Ni}-\mathrm{Ti}$ alloy. Note: DLC, diamond-like carbon.

antibiotic-antimycotic, trypsin-ethylenediamine tetra acetic acid, and L-glutamine were from Invitrogen, (CA, USA). 3-(4,5 dimethyl thiazol-2yl)-2,5 diphenyltetrazolium bromide (MTT), glutaraldehyde, osmium tetroxide, paraformaldehyde, and dimethyl sulfoxide were purchased from Sigma Aldrich. All the cell culture plasticwares were procured from BD Falcon and Thermo Scientific Nunc ${ }^{\mathbb{R}}$. All other chemicals and solvents used were of the highest available purity. The detailed procedure has been given elsewhere. ${ }^{[22]}$

\section{Results and Discussion}

Figure 1 shows FESEM images of the PIII-C + DLC coating on $\mathrm{Ni}-\mathrm{Ti}$ alloy. Figure 1(a) presents the surface morphology of

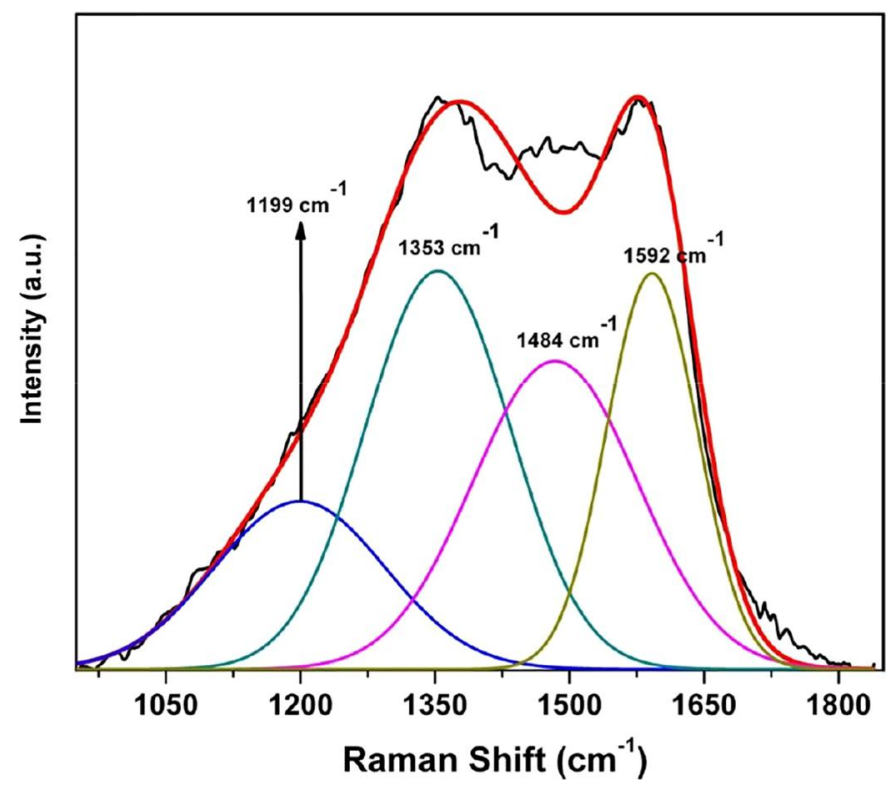

Figure 3. Raman spectrum of PIII-C + DLC-coated $\mathrm{Ni}-\mathrm{Ti}$ alloy. Note: DLC, diamond-like carbon. 

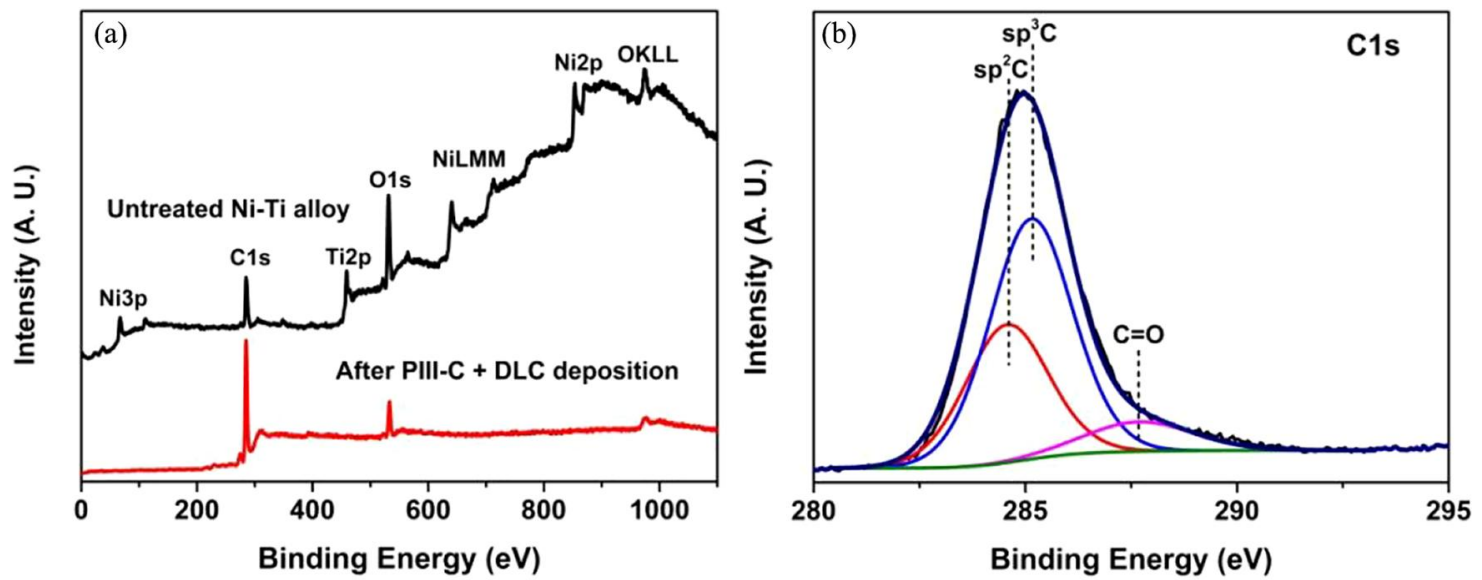

Figure 4. XPS of (a) survey spectra of untreated $\mathrm{Ni}-\mathrm{Ti}$ alloy and PIII-C + DLC-coated $\mathrm{Ni}-\mathrm{Ti}$ alloy and (b) $\mathrm{C} 1 \mathrm{~s}$ core level spectrum of PIII-C + DLC-coated Ni-Ti alloy. Note: XPS, X-ray photoelectron spectroscopy; DLC, diamond-like carbon.

the coating exhibiting some nanoroughness. Dense pore-free coating is observed on the top of the $\mathrm{Ni}-\mathrm{Ti}$ alloy. Figure 1 (b) presents the cross-sectional image of $240 \mathrm{~nm}$-thick coating on silicon substrate and there is no delamination and cracks observed after exposing to atmosphere.

The concentrations of $\mathrm{Ni}$ and $\mathrm{Ti}$ are 48.7 and 51.3 at.\%, respectively, in untreated $\mathrm{Ni}-\mathrm{Ti}$ alloy. However, concentrations of $\mathrm{C}, \mathrm{Ni}$, and $\mathrm{Ti}$ are $63.9,20.5$, and 15.6 at.\%, respectively, in PIII-C + DLC-coated alloy. It is clear from EDS data that predominant amount of carbon is formed in PIII-C + DLCcoated alloy.
Surface topographic images of the untreated and PIII-C + DLC-coated alloys are shown in Fig 2(a and b). Rough and nonhomogeneous surface is found on the untreated alloy with average and RMS roughness values of 2.2 and $2.7 \mathrm{~nm}$, respectively. However, in PIII-C + DLC-coated sample, similar surface features with average roughness of $2.7 \mathrm{~nm}$ are observed.

Raman spectrum of PIII + DLC-coated $\mathrm{Ni}-\mathrm{Ti}$ alloy is shown in Fig. 3. To get good fit, the spectrum has been deconvoluted by four Gaussian peaks after background subtraction. ${ }^{[23,24]}$ The observed peaks at 1353 and $1592 \mathrm{~cm}^{-1}$
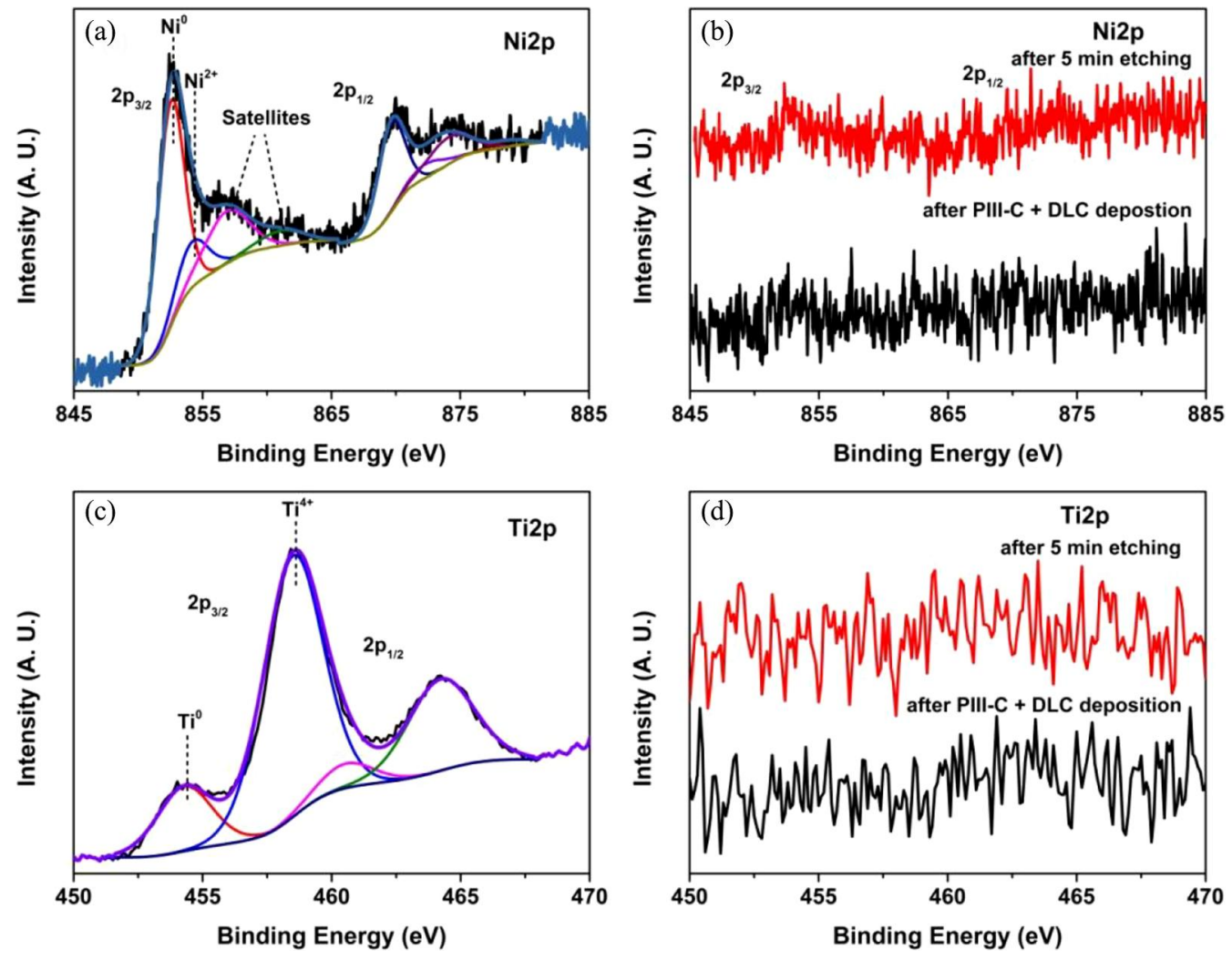

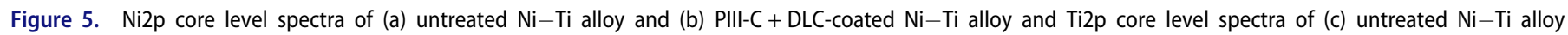
and (d) PIII-C + DLC-coated Ni-Ti alloy. Note: DLC, diamond-like carbon. 
of the top DLC layer of the coating are denoted as D and G peaks, respectively. D peak is associated with the disordered breathing mode of $\mathrm{sp}^{2}$ site and $\mathrm{G}$ peak corresponds to the stretching vibrations of any pair of $\mathrm{sp}^{2}$ sites in chains or aromatic rings. $I_{\mathrm{D}} / I_{\mathrm{G}}$ value is derived from peak fitting of Raman spectrum and the ratio of the integrated area under the $\mathrm{D}$ and $\mathrm{G}$ peaks. The evaluated $I_{\mathrm{D}} / I_{\mathrm{G}}$ ratio is 0.99 .

$\mathrm{X}$-ray photoelectron spectroscopy characterization has been performed in details to understand the surface nature of untreated and PIII-C + DLC-coated Ni-Ti alloys. Survey spectra of both $\mathrm{Ni}-\mathrm{Ti}$ alloys are presented in Fig. 4(a). Survey spectrum of untreated alloy clearly shows the presence of nickel, titanium, carbon, and oxygen. There is a huge increase in C1s core level peak intensity after carbon implantation and DLC deposition on $\mathrm{Ni}-\mathrm{Ti}$ alloy surface as observed in the respective survey spectrum. It is important to note that observed carbon in untreated alloy is adventitious carbon. The higher carbon intensity in the alloy surface after PIII-C and DLC deposition indicates the enrichment of the surface with carbon. C1s core level spectrum of PIII-C + DLC-coated alloy is asymmetrical and can be curve-fitted into several component peaks which is shown in Fig. 4(b). Accordingly, peaks at 284.6, 285.2, and $287.7 \mathrm{eV}$ in PIII-C + DLC-coated alloy are attributed to $\mathrm{sp}^{2} \mathrm{C}(\mathrm{C}=\mathrm{C}), \mathrm{sp}^{3} \mathrm{C}(\mathrm{C}-\mathrm{C})$, and $\mathrm{C}=\mathrm{O}$ species, respectively ${ }^{[24,25]}$ indicating the formation of DLC coating on the surface. Formation of this type of DLC coating on Ti$\beta 21 S$ alloy has been demonstrated by Mohan et al. ${ }^{[26]}$ In the present study, DLC layer has been formed over $\mathrm{Ni}-\mathrm{Ti}$ alloy.

Figure 5(a) shows XPS of Ni2p and Ti2p core levels from the untreated and PIII-C + DLC-coated alloys. The spectrum of untreated alloy has been decomposed to various components of Ni by curve fitting. Accordingly, Ni2 $\mathrm{p}_{3 / 2,1 / 2}$ peaks at 852.8, 870.1 and 854.4, 872.5 eV along with corresponding satellite peaks are assigned for $\mathrm{Ni}^{0}$ and $\mathrm{Ni}^{2+}$ species, respectively. ${ }^{[12,13]}$ The concentration of the oxide peak of $\mathrm{Ni}$ in the untreated alloy is very low and nickel is mostly present as $\mathrm{Ni}^{0}$. However, intensities of $\mathrm{Ni} 2 \mathrm{p}_{3 / 2,1 / 2}$ peaks decrease drastically after carbon implantation of $\mathrm{Ni}-\mathrm{Ti}$ alloy substrate as seen from Fig. 5(b) indicating that PIII-C + DLC layers cover the entire surface. Intensities of $\mathrm{Ni}_{2} \mathrm{p}_{3 / 2,1 / 2}$ peaks are observed to increase after mild sputter etching of the PIII-C+ DLC-coated alloy surface (Fig. 5(b)). Ti2p spectrum of the untreated alloy is broad and can be curve-fitted into component peaks (Fig. $5(\mathrm{c})$ ). Two sets of decomposed $2 \mathrm{p}_{3 / 2,1 / 2}$ peaks observed at 454.4, 460.6 and $458.6,464.3 \mathrm{eV}$ are related to $\mathrm{Ti}^{0}$ and $\mathrm{Ti}^{4+}$ species, respectively. ${ }^{[12,13,26]}$ There is no trace of Ti2p peaks after PIII-C + DLC deposition (Fig. 5(d)). They are not observed even after $\mathrm{Ar}^{+}$sputter etching indicating the formation of carbon layer on the alloy surface after PIII-C + DLC deposition.

Potentiodynamic polarization curves of untreated and PIII-C + DLC-coated Ni-Ti alloy samples are depicted in Fig. 6(top). Corrosion current density is derived from polarization curve by extrapolation of its anodic and cathodic branches. Corrosion potential $\left(E_{\text {corr }}\right)$ and corrosion current density $\left(i_{\text {corr }}\right)$ values of untreated $\mathrm{Ni}-\mathrm{Ti}$ alloy are $-0.354 \mathrm{~V}$ and $0.0665 \mu \mathrm{A} \mathrm{cm}^{-2}$, respectively. In PIII-C + DLC-coated sample, more positive $E_{\text {corr }}$ value of $-0.175 \mathrm{~V}$ and lower $i_{\text {corr }}$ value of $0.0013 \mu \mathrm{A} \mathrm{cm}^{-2}$ are observed. The nobler shift and lower passivation current density clearly demonstrate the higher corrosion resistance of the PIII-C +DLC-coated alloy.

Figure 6(bottom) also depicts the EIS plots of the untreated and PIII-C + DLC-coated Ni-Ti alloy as Bode plots. The phase angle rapidly increases from higher frequency $(100 \mathrm{kHz})$ to mid frequency $(10 \mathrm{~Hz})$ and attains a constant phase angle of $-85^{\circ}$ at the frequency range of $0.1-10 \mathrm{~Hz}$ and then decreases to $-71^{\circ}$. In the case of PIII-C + DLC-coated alloy, phase angle rapidly increases from $-50^{\circ}$ at 100 to $1 \mathrm{kHz}$ frequency range, reaching to a peak at around $-70^{\circ}$ and decreases again to around $-45^{\circ}$ at $10 \mathrm{~Hz}$. At lower frequency range (10 to 0.01 $\mathrm{Hz}$ ), the phase angle gradually increases and attains nearly $-85^{\circ}$ which is less than $-90^{\circ}$, the value for ideal capacitor.

Equivalent circuit (EC) diagrams used to interpret the EIS data are also shown in Fig. 6(bottom). The EC diagram of untreated $\mathrm{Ni}-\mathrm{Ti}$ alloy possesses two time constants that
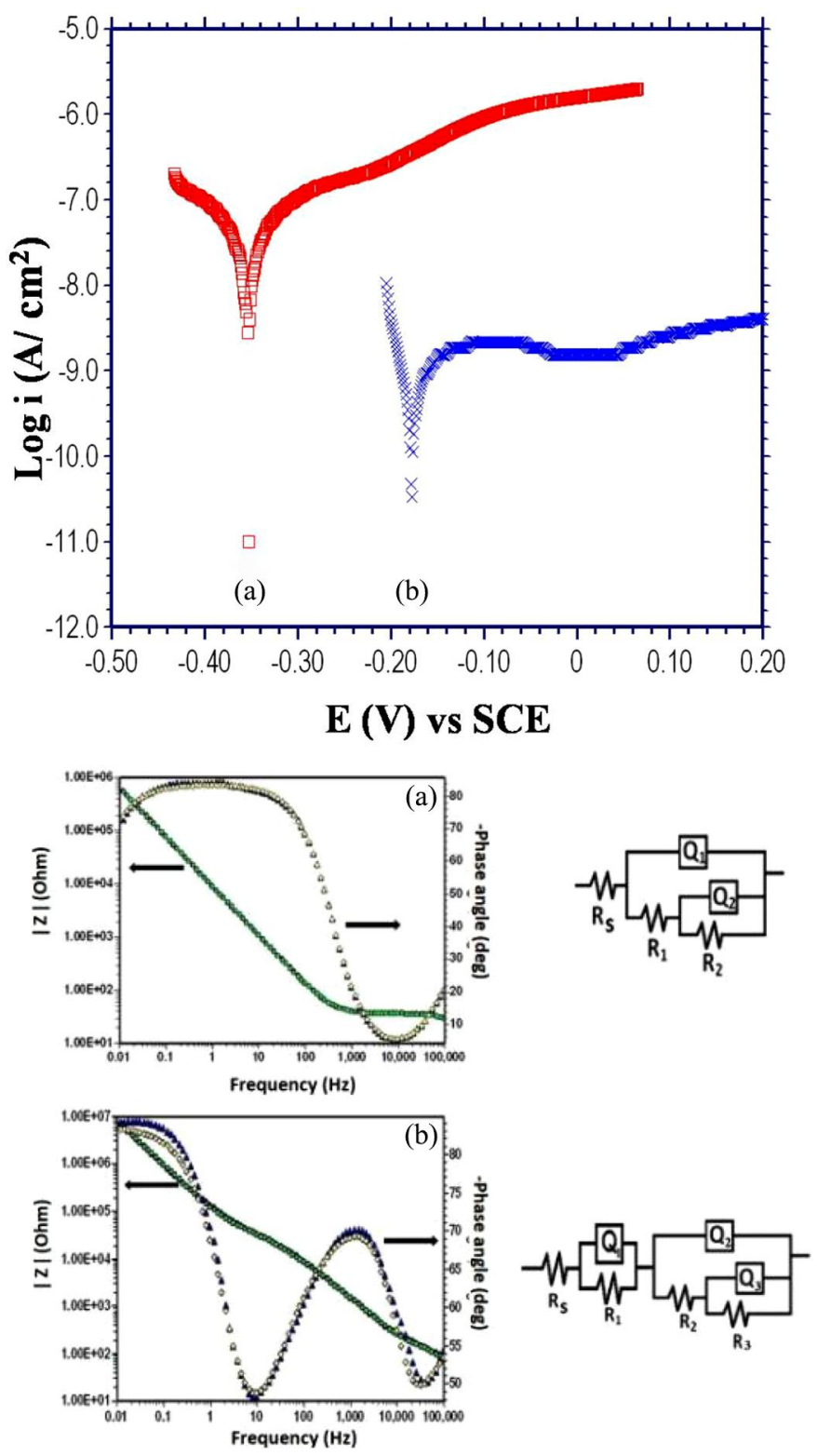

Figure 6. Tafel plots (top panel) and Bode plots and EC diagram (bottom panel) of (a) untreated $\mathrm{Ni}-\mathrm{Ti}$ alloy and (b) PIII-C + DLC-coated Ni-Ti alloy in Hanks' solution. Note: DLC, diamond-like carbon; EC, equivalent circuit. 
Table 1. Electrochemical impedance parameters obtained by fitting equivalent circuit models for untreated Ni-Ti alloy and PIII-C $+\mathrm{DLC}-$ coated Ni-Ti alloy.

\begin{tabular}{|c|c|c|c|c|c|c|c|c|c|c|}
\hline Sample & $R_{\mathrm{s}}\left(\Omega \mathrm{cm}^{2}\right)$ & $Q_{1}\left(S \mathrm{~s}^{n} \mathrm{~cm}^{-2}\right)$ & $n_{1}$ & $R_{1}\left(\Omega \mathrm{cm}^{2}\right)$ & $Q_{2}\left(S s^{n} \mathrm{~cm}^{-2}\right)$ & $n_{2}$ & $R_{2}\left(\Omega \mathrm{cm}^{2}\right)$ & $Q_{3}\left(\mathrm{~S} \mathrm{~s}^{n} \mathrm{~cm}^{-2}\right)$ & $n_{3}$ & $\mathrm{R}_{3}\left(\Omega \mathrm{cm}^{2}\right)$ \\
\hline Untreated $\mathrm{Ni}-\mathrm{Ti}$ alloy & 15.4 & $7.34 \times 10^{-8}$ & 0.99 & 21 & $1.98 \times 10^{-5}$ & 0.93 & $3.1 \times 10^{6}$ & - & - & - \\
\hline
\end{tabular}

DLC, diamond-like carbon.

consist of $R_{\mathrm{s}}, R_{1}$, and $R_{2}$ representing the solution resistance, outer pores oxide layer resistance, and inner barrier layer resistance, respectively, which is in line with our previous works. ${ }^{[12,13,22]} Q_{1}$ and $Q_{2}$ represent the capacitance of the outer layer and inner layer, respectively. Obtained EIS parameter values of untreated alloy are shown in Table $1 . R_{1}$ value is $21 \Omega \mathrm{cm}^{2}$ and that of $R_{2}$ is $3.1 \times 10^{6} \Omega \mathrm{cm}^{2}$ which shows higher corrosion resistance value. The constant phase element (n) values for outer and inner barrier layers are 0.99 and 0.93 , respectively. In the case of PIII-C + DLC-coated alloy, the bilayered structure has been fitted with three time constants.
$R_{\mathrm{s}}, R_{1}$, and $Q_{1}$ correspond to solution resistance, outer porous layer/pin holes resistance, and related capacitance, respectively. $R_{2}$ and $Q_{2}$ represent dense DLC coating layer resistance and its capacitance and similarly, $R_{3}$ and $Q_{3}$ are associated with inner barrier of PIII-C layer resistance and its capacitance. Obtained EIS parameter values of PIII-C + DLC-coated sample are also given in Table 1 . The values of $R_{1}$ and $R_{2}$ are 393.3 and $3.6 \times 10^{4} \Omega \mathrm{cm}^{2}$, respectively. Inner PIII-C layer exhibits high corrosion resistance $\left(R_{3}\right)$ of $3.6 \times 10^{6} \Omega \mathrm{cm}^{2}$. The values of $n$ representing the outer layer, dense DLC coating layer, and inner PIII-C layer are 0.68, 0.95, and 0.92,
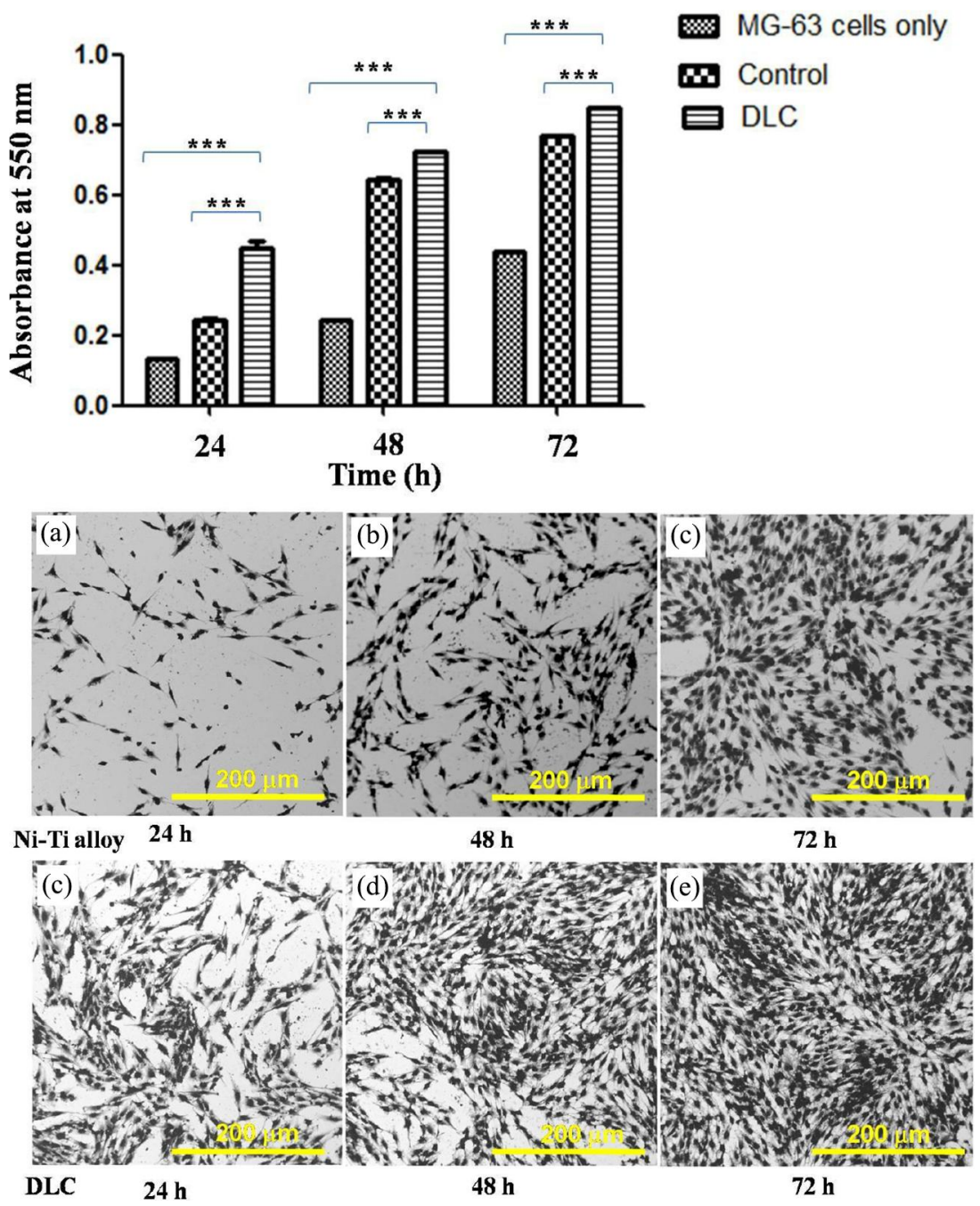

Figure 7. (Top panel) Evaluation of cell viability by MTT assays on Ni-Ti substrate and PIII-C + DLC samples. MG-63 cells $\left(1.0 \times 10^{4}\right)$ were seeded separately on Ni-Ti alloy and PIII-C + DLC and cultured for 24, 48, and $72 \mathrm{~h}$. Viability of cells were determined by MTT assay as described in Materials and Methods by measuring absorbance at $\mathrm{OD}_{550}$ shown by viable cells only. Cell only and $\mathrm{Ni}-\mathrm{Ti}$ alloy were used as controls. The OD values of PIII-C + DLC were higher than controls indicating higher cell viability. Asterisk (*): Cell proliferation were significantly different from controls $(p<0.0001)$. Each bar represents an average of three replicates \pm SD. (Bottom panel) Detection of cell morphology by SEM: MG-63 cells seeded on Ni-Ti alloy ( $a, b, c)$ and PIII-C + DLC (d, e, f) and incubated for 24, 48, and 72 h, respectively. All the microstructures were taken at $300 \times$ magnification. As seen in the images, cells were attached firmly on the samples and cell growth were higher on PIII-C + DLC than Ni-Ti alloy for all the three time periods as well as exhibited intimate attachment on the surface through filopodial extensions. Note: DLC, diamond-like carbon; MTT, 3-(4,5 dimethyl thiazol-2yl)-2,5 diphenyltetrazolium bromide. 
respectively. Thus, better corrosion resistance property is observed in PIII-C + DLC-coated $\mathrm{Ni}-\mathrm{Ti}$ alloy compared to untreated $\mathrm{Ni}-\mathrm{Ti}$ alloy as evident from potentiodynamic polarization and EIS studies.

3-(4,5 Dimethyl thiazol-2yl)-2,5 diphenyltetrazolium bromide assay has been used to detect the cytotoxicity of $\mathrm{Ni}-\mathrm{Ti}$ alloy and PIII-C + DLC-coated alloy on osteoblast-like cells (MG-63) [Fig. 7 (top)]. There are significant enhancement of viable cells adhered on both untreated and PIII-C + DLCcoated alloys as reflected in increased absorbance; optical density $\left(\mathrm{OD}_{550 \mathrm{~nm}}\right)$ being $0.245 \pm 0.007$ vs. $0.446 \pm 0.035$ after $24 \mathrm{~h}$ of incubation compared to cell only $(0.132 \pm 0.0005)$. OD values of PIII-C + DLC-coated alloy are much higher ( $\sim 1.8$ fold) than that of untreated alloy. ${ }^{[2]}$ The numbers of viable cells further increase after incubation for 48 and $72 \mathrm{~h}$. No apparent cytotoxicity is observed even after longer incubation; OD being $0.243 \pm 0.001,0.643 \pm 0.003$, and $0.721 \pm 0.0047$ vs. $0.438 \pm 0.001,0.767 \pm 0.003$, and $0.847 \pm$ 0.001 for cell only, $\mathrm{Ni}-\mathrm{Ti}$ alloy, and PIII-C + DLC-coated alloy after 48 and $72 \mathrm{~h}$, respectively.

Scanning electron microscopy images confirm the attachment of MG-63 cells on both the $\mathrm{Ni}-\mathrm{Ti}$ alloy and PIII-C + DLC-coated alloy after the 24, 48, and $72 \mathrm{~h}$ of incubation [Fig. 7 (bottom)]. The cells have well-spread morphology indicating that they are firmly anchored on the surface of the substrate. The cell growth increases with an increase in incubation time compared to cell only.

\section{Conclusions}

In the present work, well-adhered DLC coating has been deposited on $\mathrm{Ni}-\mathrm{Ti}$ alloy by combination of PIII-C and PECVD methods. Raman spectroscopy and XPS studies show the formation of dense PIII-C + DLC coating on the $\mathrm{Ni}-\mathrm{Ti}$ alloy surface. Electrochemical studies have demonstrated that the coated $\mathrm{Ni}-\mathrm{Ti}$ alloy has improved corrosion resistance properties in SBF. Ni-Ti alloy and PIII-C + DLC-coated alloy show no cytotoxicity on MG-63 cells which is supported by the morphological study of attached cells.

\section{Acknowledgments}

This work was performed under the Council of Scientific \& Industrial Research network project on BIOCERAMICS (ESC-01-03) and Indian Council of Medical Research (URL - http://www.icmr.nic.in/) (GAP 294), Government of India. The authors would like to thank the Directors, CSIR-National Aerospace Laboratories, Bengaluru and CSIR-Indian Institute of Chemical Biology, Kolkata for their support and permission to publish the work.

\section{Funding}

This work was supported by CSIR, India [Grant number ESC-01-03].

\section{References}

[1] Tosun, G.; Tosun, N. Analysis of Process Parameters for Porosity in Porous NiTi Implants. Mater. Manuf. Processes. 2012, 27(11), 1184-1188. DOI: 10.1080/10426914.2011.648692.
[2] Mirshekari, G. R.; Kermanpur, A.; Saatchi, A.; Sadrnezhaad, S. K.; Soleymani, A. P. Microstructure, Cyclic Deformation and Corrosion Behavior of Laser Welded NiTi Shape Memory Wires. J. Mater. Eng. Perform. 2015, 24(9), 3356-3364. DOI: 10.1007/ s11665-015-1614-y.

[3] Marchand, C.; Heim, F.; Durand, B.; Chafke, N. Nitinol Stent for Percutaneous Heart Valve Implantation: Material Shape Setting. Mater. Manuf. Processes. 2011, 26(2), 181-187. DOI: 10.1080/ 10426914.2010.491695

[4] Gill, P.; Musaramthota, V.; Munroe, N.; Datye, A.; Dua, R.; Haider W.; McGoron, A.; Rokicki, R. Surface Modification of Ni-Ti Alloys for Stent Application after Magnetoelectropolishing. Mater. Sci. Eng. C. 2015, 50, 37-44. DOI: 10.1016/j.msec.2015.01.009.

[5] Ayers, R.; Burkes, D.; Gottoli, G.; Yi, H. C.; Moore, J. J. The Application of Self-Propagating High-Temperature Synthesis of Engineered Porous Composite Biomedical Materials. Mater. Manuf. Processes. 2007, 22(4), 481-488. DOI: 10.1080/ 10426910701235967.

[6] Wang, Q.; Zhang, S.; Zhang, C.; Wu, C.; Sun, Z. Tailoring the Surface of NiTi Alloy by TiN Coating for Biomedical Application. Mater. Technol. 2017, 32(11), 657-667. DOI: 10.1080/10667857. 2017.1321277.

[7] Liu, Y.; Ren, Z.; Bai, L.; Zong, M.; Gao, A.; Hang, R.; Jia, H.; Tang, B.; Chu, P. K. Relationship Between Ni Release and Cytocompatibility of Ni-Ti-O Nanotubes Prepared on Biomedical NiTi Alloy. Corros. Sci. 2017, 123, 209-216. DOI: 10.1016/j.corsci. 2017.05.006.

[8] Spriano, S.; Balagna, C.; Ferri, A.; Dotti, F.; Villa, E.; Nespoli, A; Tori, A. Processing and Surface Treatments for Pseudoelastic Wires and Strands. Mater. Manuf. Processes. 2017, 32(4), 394-403. DOI: $10.1080 / 10426914.2016 .1198031$

[9] Saedi, S.; Turabi, A. S.; Andani, M. T.; Haberland, C.; Karaca, H.; Elahinia, M. The Influence of Heat Treatment on the Thermomechanical Response of Ni-Rich NiTi Alloys Manufactured by Selective Laser Melting. J. Alloys Compd. 2016, 677, 204-210. DOI: 10.1016/j. jallcom.2016.03.161.

[10] Liu, J.-X.; Yang, D.-Z.; Shi, F.; Cai, Y.-J. Sol-Gel Deposited $\mathrm{TiO}_{2}$ Film on NiTi Surgical Alloy for Biocompatibility Improvement. Thin Solid Films. 2003, 429(1-2), 225-230. DOI: 10.1016/s00406090(03)00146-9.

[11] Hang, R.; Liu, Y.; Liu, S.; Bai, L.; Gao, A.; Zhang, X.; Huang, X.; Tang, B.; Chu, P. K. Size-Dependent Corrosion Behavior and Cytocompatibility of Ni-Ti-O Nanotubes Prepared by Anodization of Biomedical NiTi Alloy. Corros. Sci. 2016, 103, 173-180. DOI: 10.1016/j.corsci.2015.11.016

[12] Viswanathan, S.; Mohan, L.; John, S.; Bera, P.; Anandan, C. Effect of Surface Finishing on the Formation of Nanostructure and Corrosion Behavior of Ni-Ti Alloy. Surf. Interface Anal. 2017, 49(5), 450-456. DOI: $10.1002 /$ sia.6178.

[13] Viswanathan, S.; Mohan, L.; Bera, P.; Anandan, C. Effect of Oxygen Plasma Immersion Ion Implantation on the Formation of Nanostructures Over Ni-Ti Alloy. RSC Adv. 2016, 6(78), 74493-74499. DOI: 10.1039/c6ra11541a.

[14] Slabodchikov, V. A.; Borisov, D. P.; Kuznetsov, V. M. Effect of Bias Voltage on Coating Homogeneity in Plasma Immersion Ion Implantation. AIP Conference Proceedings, Tomsk, Russia, 2016, 1783(1), Article No. 020209. DOI:10.1063/1.4966503.

[15] Kashin, O. A.; Lotkov, A. I.; Kudryashov, A. N.; Krukovsky, K. V.; Ostapenko, M. G.; Neiman, A. A.; Borisov, D. P. Structural Phase States in Nickel-Titanium Surface Layers Doped with Silicon by Plasma Immersion Ion Implantation. AIP Conference Proceedings, Tomsk, Russia. 2015, 1683(1), Article No. 020078. DOI: 10.1063/ 1.4932768

[16] Lu, T.; Qiao, Y.; Liu, X. Surface Modification of Biomaterials Using Plasma Immersion Ion Implantation and Deposition. Interface Focus 2012, 2(3), 325-336. DOI: 10.1098/rsfs.2012.0003

[17] Slabodchikov, V. A.; Borisov, D. P.; Kuznetsov, V. M. Effect of Preliminary Vacuum Plasma Treatment on Coating Adhesion. AIP Conference Proceedings, Tomsk, Russia, 2016, 1783(1), Article No. 020210. DOI: 10.1063/1.4966504. 
[18] Muguruma, T.; Iijima, M.; Nagano-Takebe, F.; Endo, K.; Mizoguchi, I. Frictional Properties and Characterization of a Diamond-Like Carbon Coating Formed on Orthodontic Stainless Steel. J. Biomater. Tissue Eng. 2017, 7(2), 119-126. DOI: 10.1166/jbt.2017.1553.

[19] Niiyama, Y.; Takeno, T.; Kurihara, K.; Adachi, K. Effect of Sliding History on Super-Low Friction of Diamond-Like Carbon Coating in Water Lubrication. Tribol. Lett. 2017, 65(2), Article No. 63. DOI: 10.1007/s11249-017-0849-1.

[20] Ankit, K.; Varade, A.; Reddy, K. N.; Dhan, S.; Chellamalai, M.; Balashanmugam, N.; Krishna, P. Synthesis of High Hardness IR Optical Coating Using Diamond-Like Carbon by PECVD at Room Temperature. Diamond Relat. Mater. 2017, 78, 39-43. DOI: 10.1016/j.diamond.2017.07.008.

[21] Mohan, L.; Viswanathan, S.; Anandan, C.; Rajendran, N. Corrosion Behaviour of Tetrahedral Amorphous Carbon (ta-C) Filled Titania Nano Tubes. RSC Adv. 2015, 5(113), 93131-93138. DOI: 10.1039/ c5ra19625f.

[22] Mohan, L.; Chakraborty, M.; Viswanathan, S.; Mandal, C.; Bera, P.; Aruna, S. T.; Anandan, C. Corrosion, Wear, and Cell Culture
Studies of Oxygen Ion Implanted Ni-Ti Alloy. Surf. Interface Anal. 2017, 49(9), 828-836. DOI: 10.1002/sia.6229.

[23] Kumar, P.; Babu, P. D.; Mohan, L.; Anandan, C.; Grips, V. K. W. Wear and Corrosion Behavior of Zr-Doped DLC on Ti-13Zr-13Nb Biomedical Alloy. J. Mater. Eng. Perform. 2013, 22(1), 283-293. DOI: $10.1007 / \mathrm{s} 11665-012-0230-3$

[24] Viswanathan, S.; Mohan, L.; Bera, P.; Kumar, V. P.; Barshilia, H. C.; Anandan, C. Corrosion and Wear Behaviors of Cr-Doped Diamond-Like Carbon Coatings. J. Mater. Eng. Perform. 2017, 26(8), 3633-3647. DOI: 10.1007/s11665-0172783-7.

[25] Santra, S.; Ranjan, P.; Bera, P.; Ghosh, P.; Mandal, S. K. Anchored Palladium Nanoparticles onto Single Walled Carbon Nanotubes: Efficient Recyclable Catalyst for N-Containing Heterocycles. RSC Adv. 2012, 2(19), 7523-7533. DOI: 10.1039/c2ra20281f.

[26] Mohan, L.; Anandan, C.; Grips, V. K. W. Corrosion Behavior of Titanium Alloy Beta-21S Coated with Diamond Like Carbon in Hank's Solution. Appl. Surf. Sci. 2012, 258(17), 6331-6340. DOI: $10.1016 /$ j.apsusc.2012.03.032. 